\title{
Quality of life and working context of nursing professionals of the Family Health Strategy
}

\author{
Qualidade de vida e contexto de trabalho de profissionais de enfermagem da Estratégia \\ Saúde da Família
}

\section{Calidad de vida y contexto de trabajo de profesionales de enfermería de la Estrategia Salud Familiar}

Ana Luisa Nunes Marques ${ }^{1}$, Maria Beatriz Guimarães Ferreira², Joyce Mara Gabriel Duarte ${ }^{1}$, Nara dos Santos Costa $^{1}$, Vanderlei José Haas ${ }^{1}$, Ana Lúcia de Assis Simões ${ }^{1}$

\begin{abstract}
Objective: to examine the relationship between working context and quality of life of nursing professionals of the Family Health Strategy. Methods: observational, cross-sectional study with quantitative approach accomplished with 50 nursing professionals from urban and rural areas. Participants answered a questionnaire of socio-demographic and professional characterization, the Work Context Assessment Scale and WHOQOL-brief. Data were submitted to exploratory and bivariate analysis. Results: predominance of women, married, belonging to economic classes C/D and with only one employment bond. The factor Work Organization and the Social domain had higher mean scores, while Socio-professional relations and the Environmental domain, lower scores. Descriptively, there was a negative correlation between all the factors of the work context and the Physical, Psychological and Social domains. Conclusion: inadequate conditions to work practice, lack of organization and the difficulty in social relationships negatively impact the quality of life of nursing professionals.

Descriptors: Nursing, Team; Working Conditions; Quality of Life; Family Health Strategy.
\end{abstract}

Objetivo: analisar a relação do contexto de trabalho e a qualidade de vida dos profissionais de enfermagem da Estratégia Saúde da Família. Métodos: estudo observacional, seccional, de abordagem quantitativa, realizado com 50 profissionais de enfermagem das zonas urbana e rural. Participantes responderam Questionário de caracterização sociodemográfica e profissional, Escala de Avaliação de Contexto de Trabalho e WHOQOL-bref. Dados foram submetidos à análise exploratória e bivariada. Resultados: predomínio de mulheres, casadas, pertencentes às classes econômicas C/D e único vínculo empregatício. 0 fator Organização do Trabalho e o domínio Social apresentaram maiores escores médios, enquanto as Relações Socioprofissionais e o domínio Ambiental, menores escores. Descritivamente, houve correlação negativa entre todos os fatores do contexto de trabalho e os domínios Físico, Psicológico e Social. Conclusão: condições inadequadas para exercer o trabalho, a falta de organização e a dificuldade nas relações sociais impactam negativamente a qualidade de vida dos profissionais de enfermagem.

Descritores: Equipe de Enfermagem; Condições de Trabalho; Qualidade de Vida; Estratégia Saúde da Família.

Objetivo: analizar la relación del contexto de trabajo y la calidad de vida de profesionales de enfermería de la Estrategia de Salud Familiar. Métodos: estudio observacional, transversal, seccional, de enfoque cuantitativo, realizado con 50 profesionales de enfermería de las zonas urbana y rural. Participantes respondieron al cuestionario de caracterización sociodemográfica y profesional, Escala de Evaluación de Contexto de Trabajo y WHOQOL-bref. Datos sometidos a análisis exploratorio y bivariado. Resultados: predominio de mujeres, casadas, pertenecientes a las clases socioeconómicas C/D y de empleo único. Organización del Trabajo y ámbito social presentaron puntuaciones más altas, mientras las Relaciones socioeconómicas y el dominio Ambiental, puntuaciones más bajas. Descriptivamente, hubo correlación negativa entre todos los factores del contexto de trabajo y los dominios Físico, Psicológico y Social. Conclusión: condiciones inadecuadas para ejercer el trabajo, falta de organización y dificultad en las relaciones sociales impactan negativamente la calidad de vida de profesionales de enfermería.

Descriptores: Grupo de Enfermería; Condiciones de Trabajo; Calidad de Vida; Estrategia de Salud Familiar.

\footnotetext{
${ }^{1}$ Universidade Federal do Triângulo Mineiro. Uberaba, MG, Brazil.
}

${ }^{2}$ Universidade de São Paulo. Ribeirão Preto, SP, Brazil. 


\section{Introduction}

In face of the need to transform health services and envisaging an integral model of care to replace the individual model, the Ministry of Health established several initiatives aiming to seek for a change in the health care model over the past ten years. Among these are the Family Health Program, in place since 1994, the National Policy on Basic Care, since 2006, and the Centers of Support for Family Health, since 2008. Even after implementation of these programs, the Health System yet find barriers to be overcome in order to concretize them. The modification of the standard curative model to the preventive model and the establishment of regionalized and hierarchical network are some of the barriers to the effective consolidation of these programs ${ }^{(1)}$.

It is noteworthy that due to the versatility, understanding of the health problems in their ascribed local context and horizontalization of health practices, the Health Family Program in 1996 passed to be understood and termed as the Family Health Strategy ${ }^{(1-2)}$.

For health professionals, the implementation of FHS may denote the revaluation of techniques, values and knowledge of each one of them, because this work requires greater complexity of activities to be undertaken in pursuit of biopsychosocial well-being of users ${ }^{(2)}$.

Nursing professionals play the role of extended lead over other professionals, adding to this function, the care and management activities and survey of interfering factors in the health-disease process, recognizing the specific characteristics/requirements of each individual ${ }^{(3)}$.

As for the health condition of nursing workers inserted in primary care, we highlight the occupational risk factors inherent to the work and also new critical points of influence, as the responsibility to organize work processes, meet population demands and the follow-up of the directions governing the organization of Primary Care as a whole ${ }^{(4)}$.
In the field of health work management, it is pertinent to evaluate, beyond the context, the course of the work process, individual practices, interests relating to the examination of negotiations during the execution of the activity, as well as factors that consume energies and those that cause well-being at $\operatorname{work}^{(5)}$.

The working environment founded on the Taylorist shape in the Family Health Strategy (division of tasks, activities performed with the same frequency and sequence, control of the exercise and lack of communication among professionals) adds to the imbalance and lack of indispensable resources for the course of labor activities that cause human burden, both psychophysical and affective, concerning to the efforts made toward caring for users ${ }^{(5)}$.

In order to offer quality of service for users and to promote effective health activities, the care provider, that is, the health professional must have quality of life, since the factors that interfere with this context can influence the quality of care directed to the population ${ }^{(2)}$.

Quality of life is defined, therefore, as the perception that the individual has in relation to his/ her position in life, the context in which he/she lives and as to his/her goals, expectations, standards and concerns $^{(6)}$.

To a larger extent, quality of life can be seen as connected to physical, technological, psychological and social factors at work. It also involves satisfaction, mutual respect among individuals and participation of the worker in a way that he/she performs his/her functions with satisfaction and acknowledgement ${ }^{(7)}$.

It is vital to know the quality of life of nursing professionals involved in the context of the Family Health Strategy so that the actions aimed to promote well-being be planned favoring job duties ${ }^{(2)}$.

Primary care figures as the sector that accounts for the majority of actions aimed at health promotion and risk control, representing an area of action where there is a large concentration of nursing workforce. Currently, a more significant number of studies 
are directed toward workers' health in hospital environments, reinforcing the persistent division between the levels of complexity of care service. The interest in developing studies related to the influence of the quality of life of nursing professionals in patient care, combined with the scant amount of research to primary care, fosters studies to further deepening this theme.

Seeking to enrich the debate and the production of knowledge in the area, the investigation of the quality of life of nursing professionals is to encourage the improvement of public health policies and assistance to the user community.

Given the above, understanding the impact of the working context on the quality of life of the Family Health Strategy nurses can guide actions to minimize the organizational stressors and to promote the quality of life of the professional.

This study had as objective to analyze the relationship of the working context and quality of life of Family Health Strategy nurses of a municipality of Minas Gerais.

\section{Method}

This is an observational, cross-sectional study with quantitative approach and participation of nursing staff professionals linked to the Family Health Strategy, including nurses and nursing technicians from rural and urban areas of a countryside municipality in Minas Gerais. During the period of data collection, the municipality had 50 Family Health Teams, 46 in the urban area and four in the rural area, integrated into 26 health units, 22 in the urban area and four in the rural area.

The study belongs to a larger project and thus all nursing professionals were selected resulting in a sample size among nurses and nursing technicians ( $\mathrm{n}=50$ ). All subjects signed the Informed Consent before data collection. Data collection was conducted by a group of researchers in meetings with nurses previously scheduled and authorized by the managers of health units from September 2013 to January 2014. The following instruments were used for data collection: socio-demographic and professional characterization questionnaire; Work Context Assessment Scale and World Health Organization Quality of Life (WHOQOL-brief). Data collection was performed by self-application of the instruments.

The characterization questionnaire analyzed individuals based on socioeconomic classification criteria of Brazil provided by the Brazilian Association of Research Companies. Scores are conferred according to possession of items, and the sum corresponds to economic classes, which represent the economic strata (A, B, C, D and E), so that upper classes such as $A$ and $B$ have higher acquisitive power.

Work Context Assessment Scale is a scale that has been validated in a study involving 5,437 employees of federal companies in the Federal District ${ }^{(8)}$. It is composed by three factors, namely: Work organization - expresses division of tasks, norms controls and pace of work and consists of 11 items; Working conditions - reveals the quality of the physical environment, workplace, equipment and materials available to perform the work and consists of 10 items; and Socio-professional relations - expresses the way of management, communication and professional interaction and consists of 10 items. Responses are also obtained through the Likert scale with scores ranging from 1 to 5 ; the lower the score, the better the result, being positive and productive at work. The higher the score, the worse the result, indicating high risk of becoming ill and need for immediate action in order to eliminate and/or mitigate causes ${ }^{(8)}$.

The WHOQOL-brief is an abbreviated version of the World Health Organization Quality of Life - 100 (WHOQOL 100), endorsed ${ }^{(6)}$ in Brazil and composed of 26 questions. The first two questions have a general nature and the other 24 represent facets of the original instrument. It evaluates four domains: Physical (pain and discomfort, energy and fatigue, sleep and rest, mobility, activities of daily life, dependence on medication or treatments and work capacity); 
Psychological (positive feelings, thinking, learning, memory and concentration, self-esteem, body image and appearance, negative feelings, spirituality, religion and personal beliefs); Social relationships (personal relationships, social support [backing], sexual activity) and Environment (physical safety and protection, home environment, financial resources, health and social care: accessibility and quality, opportunity to acquire new information and skills, participation/opportunities for recreation/leisure, physical environment: pollution, noise, traffic, climate and transport). The answers are obtained through the Likert scale with scores ranging from 1 to 5 , so that the higher the score, the better the professional feels about his/her quality of life. The WHOQOL-brief syntax provided by the World Health Organization was used for attainment of scores for each domain ${ }^{(6)}$.

Data analysis was performed using the double entry technique (typing), with subsequent validation, using the Microsoft Excel application. The statistical analysis was done using the Statistical Package for the Social Sciences, version 21.

First, data were submitted to exploratory analysis using simple frequencies, measures of central tendecy (mean and median) and variability (spread and standard deviation). In the bivariate analysis, we used the Student $t$-test for variables with two groups, and Pearson's correlation to quantify the relationship between quantitative variables. Correlation values to be considered were: weak ( 0 to 0.29 ), moderate $(0.30$ 0.49 ), strong ( 0.50 to 1.0 ).

The study was approved by the Ethics Committee of the Federal University of Triangulo Mineiro, under Protocol in no 2244.

\section{Results}

Among a total of $50(100.0 \%)$ nursing team professionals, $47(94.0 \%)$ were female. The average age of professionals was 37.87 years, with standard deviation of 8.64, minimum age of 27.21 years and a maximum of 59.13 years. Regarding to marital status,
$26(52.0 \%)$ were married or living in stable union and 20 (40.0\%) had no mate.

As for the economic evaluation, there were no professionals representing classes $\mathrm{A}$ and $\mathrm{B}$. In turn, there was predominance, with 43 (86.0\%) professionals, of the classes $\mathrm{D}$ and $\mathrm{E}$.

As for educational level, 27 (54.0\%) completed graduation and $23(46.0 \%)$ completed high school. With regard to professional category, 26 (52.0\%) professionals from the nursing team had the position of Nursing Technician and 24 (48.0\%) were nurses. Regarding further training, 24 (48.0\%) had specialization and a master's degree. Regarding the number of employment bonds, the majority (80.0\%) had only one employment bond (Table 1).

Table 1 - Distribution of nursing professionals according to sociodemographic and professional characteristics

\begin{tabular}{|c|c|}
\hline Variables & n (\%) \\
\hline \multicolumn{2}{|l|}{ Sex } \\
\hline Female & $47(94.0)$ \\
\hline Male & $3(6.0)$ \\
\hline \multicolumn{2}{|l|}{ Marital status } \\
\hline Single & $20(40.0)$ \\
\hline Married & $22(44.0)$ \\
\hline Divorced & $3(6.0)$ \\
\hline Separated & $1(2.0)$ \\
\hline Stable union & $4(8.0)$ \\
\hline \multicolumn{2}{|l|}{ Own house } \\
\hline Yes & $36(72.0)$ \\
\hline No & $14(28.0)$ \\
\hline \multicolumn{2}{|l|}{ Economic class } \\
\hline $\mathrm{C}$ & $7(14.0)$ \\
\hline D; E & $43(86.0)$ \\
\hline \multicolumn{2}{|l|}{ Profession } \\
\hline Nurse & $24(48.0)$ \\
\hline Nursing assistant/technician & $26(52.0)$ \\
\hline \multicolumn{2}{|l|}{ Further education } \\
\hline Specialization & $24(48.0)$ \\
\hline Master's degree & $1(2.0)$ \\
\hline None & $25(50.0)$ \\
\hline \multicolumn{2}{|l|}{ Number of employment bonds } \\
\hline One & $40(80.0)$ \\
\hline Two & $10(20.0)$ \\
\hline
\end{tabular}


As for the evaluation of the working context and quality of life, the results of exploratory analysis are presented in Table 2. It is noticeable that among the factors of work context, Work Organization had the highest mean score followed by Working Conditions and Socio-professional Relations, with lower mean score. As for Quality of life, Social domain had the highest mean score and Environmental domain had the lowest mean score.

Table 2 - Minimum and maximum values, mean score, median, standard deviation and Cronbach's alpha coefficient of the dimensions of work Context and domains of quality of life of Family Health Strategy nursing professionals

\begin{tabular}{|c|c|c|c|c|c|c|}
\hline Variable & $\begin{array}{l}\text { Mini- } \\
\text { mum }\end{array}$ & $\begin{array}{l}\text { Maxi- } \\
\text { mum }\end{array}$ & Mean & Median & $\begin{array}{l}\text { Standard } \\
\text { Deviation }\end{array}$ & Alfa \\
\hline \multicolumn{7}{|l|}{ Work context } \\
\hline Working conditions & 1.00 & 4.50 & 2.75 & 2.85 & 0.82 & 0.91 \\
\hline Work organization & 2.11 & 4.56 & 3.37 & 3.44 & 0.56 & 0.68 \\
\hline $\begin{array}{l}\text { Socio-professional } \\
\text { relationships }\end{array}$ & 1.10 & 3.60 & 2.46 & 2.60 & 0.61 & 0.81 \\
\hline \multicolumn{7}{|l|}{ Quality of life } \\
\hline Physical domain & 35.71 & 96.43 & 70.36 & 69.64 & 13.77 & 0.75 \\
\hline Psychological domain & 37.50 & 95.83 & 67.25 & 66.67 & 11.42 & 0.65 \\
\hline Social domain & 41.67 & 100.00 & 72.17 & 75.00 & 13.74 & 0.53 \\
\hline Environmental domain & 37.50 & 81.25 & 61.37 & 62.90 & 9.98 & 0.68 \\
\hline
\end{tabular}

Items with highest means in the analysis of Work Context scale were the items $3(x=3.72)$ (Is there demand for results?), $1(\chi=3.66)$ (Is the work pace accelerated?) and $2(\chi=3.58)$ (Are tasks accomplished under time-related pressure?). Items 24 $(\chi=2.06)$ (Are there difficulties in the communication supervisor-subordinate?), $30(\chi=2.14)$ (Is there lack of support by the leadership for my professional development?) And $29(\chi=2.20)$ (Is the information I need to perform my tasks difficult to assess?) had the lowest means.
Notably, items 1, 2 and 3 belong to Work Organization factor, and 24, 29 and 30, to the Socioprofessional Relations. The description is confirmed by data in the table 2 , once Work Organization factor showed the highest mean score, while Socioprofessional Relations, the lowest.

The analysis of items of the WHOQOL-brief questionnaire showed that the mean scores of items $15(\chi=4.46)$ (How well are you able to get around?), $6(\chi=4.08)$ (To what extent do you think your life is meaningful?) and $23(\chi=4.06)$ (How satisfied are you with local conditions where you live?), respectively, were the largest. The items $14(\chi=2.86)$ (To what extent do you have leisure activity opportunities?), 12 $(\chi=2.98)$ (Do you have enough money to meet your needs?) and $9(\chi=3.26)$ (How healthy is your physical environment?) had the lowest mean scores.

The items 6 and 15 belong to the Physical domain and items 9,12,14 belong to the Environmental domain. This description corroborates the mean scores between the domains of quality of life, with respect to the Physical domain having the second largest mean score and the Environmental domain, the lowest score.

In Table 3, the values of the bivariate analysis are presented. There was a weak correlation between all the work Context factors and domains of quality of life, but without statistically significant differences.

Table 3 - Bivariate analysis of the correlation between the domains of quality of life and work context factors

\begin{tabular}{lcccccc}
\hline Variables & $\begin{array}{c}\text { Working } \\
\text { conditions }\end{array}$ & $\begin{array}{c}\text { Work } \\
\text { organization }\end{array}$ & $\begin{array}{c}\text { Socio-professional } \\
\text { relations }\end{array}$ \\
\cline { 2 - 6 } & $\mathrm{r}^{*}$ & $\mathrm{p}$ & $\mathrm{r}$ & $\mathrm{p}$ & $\mathrm{r}$ & $\mathrm{p}$ \\
\hline
\end{tabular}

Domains

$\begin{array}{lcccccc}\text { Physical } & -0.01 & 0.99 & -0.09 & 0.52 & -0.15 & 0.30 \\ \text { Psychological } & -0.10 & 0.50 & -0.08 & 0.60 & -0.13 & 0.37 \\ \text { Social } & -0.12 & 0.42 & -0.26 & 0.07 & -0.17 & 0.24 \\ \text { Environmental } & 0.02 & 0.90 & 0.20 & 0.17 & -0.09 & 0.51 \\ \text { *r= Pearson's correlation coefficient } & & & & \end{array}$


Descriptively, there was a negative correlation between all factors of the work context and the Physical, Psychological and Social domains of Quality of Life. We highlight that the higher the scores, the worse the work context. Therefore, the poor conditions to practice work, lack of organization and difficulty in social relationships among professionals have a negative impact on the quality of life of the nursing professionals interviewed.

\section{Discussion}

Female sex predominates among the nursing staff. This predominance is usual since the origin of the profession, once it is associated with women's work and has the 'care' as main focus. Similar results are evident in two other studies, one with nurses (92.2\%) of the Family Health Strategy, and the other with nursing technicians (76.9\%). In both studies the females were majority ${ }^{(2,9-12)}$.

The average age found in a group of nursing team professionals in a recent study was 36.4 years, which coincides with the average age found in the present research and shows a group of professionals considered young ${ }^{(12)}$.

Most of the nursing professionals were married or living a stable union, which corroborates a study where $63.6 \%$ of the team members are in the same situation $^{(12)}$.

Research conducted in São Paulo with nursing technicians and assistants showed that the majority (63.5\%) of these professionals had their own house, which coincides with the data in the present study ${ }^{(13)}$. It was evident, too, that most of the participants belong to economic classes $\mathrm{D}$ and $\mathrm{E}$. It is worth noting that a study with the nursing team of Family Health Strategies in south of Triângulo Mineiro reported that the salaries offered to these professionals are outdated, what may explain this result ${ }^{(2)}$.

As for the educational level, the number of nurses $(52.0 \%)$ is close to the quantitative of graduated professionals (54.0\%), as well as the number of nursing technicians $(48.8 \%)$ is close to the value found for professionals with complete high school level (46.0\%). Also, the number of nurses is close to the number of professionals with specialization (48.0\%). A study conducted in Brazilian state capitals shows that most nurses (74.5\%) have at least one specialization course. Given these data, it is understood that the labor market is increasingly competitive and demanding and this makes professionals seek specialization in the area ${ }^{(14)}$.

A survey conducted in the Araguaia Valley showed that among the nursing staff, the majority (58.0\%) are nursing technicians, which does not corroborate the present study, since most of the team members have the position of nurse (52.0\%). However, the team is almost homogeneous in relation to positions held. This may be due to the fact that each team of the Family Health Strategy has approximately one nurse and one nursing technician ${ }^{(15)}$.

Research conducted in the south of Triângulo Mineiro with Family Health Strategy nurses also demonstrates the predominance of single employment bond (64.8\%) and other study with nursing technicians also reports most of participants informing a single employment bond (69.3\%). This may occur due to daily workloads practiced in the Basic Health Units which are equivalent to 8 hours, making it difficult for the professional to have another job. In the other hand, the daily 6-hours workload typical of hospital environment allows the professional to perform double work shift ${ }^{(2)}$.

The Work Organization dimension presented the highest score and is expressed by the division of labor, that is, tasks to be performed, rules and behaviors, as well as deadlines to be executed. Among the issues implied in this dimension, different positions of roles and responsibilities are factors that influence stress in overall life, in the case $f$ absence of methods that help in combat and command the worker's stress scenario( ${ }^{(8-16)}$.

Work Organization factor was the item that mostly contributes to the appearance of diseases in 
professionals when it comes to work-related context in a study with intensive care nursing professionals ${ }^{(17)}$.

In the description of results of this study, some aspects that show the relevance of work organization, namely: demands, pace and pressure. This fact corroborates a study with 243 professionals of Family Health Strategy team of the Federal District where professionals rated as critical the following aspects: division of labor; pace of work; pressure and demands, with respect to time and completion of a task. These situations demonstrate management tactics that point to the ability to produce with yield ${ }^{(5)}$.

The maintenance of the Taylorist system in the administration and work management today is evident. Such a system is characterized by the repetition of tasks, division between those planning and those performing the work, demand for results and obstacles in social and professional interactions. Increasing the collective participation of workers through unions and their representatives, as well as within services, through meetings, discussions and celebration of the agreements between departments and managers is needed in order to breakundemocratic models of work management ${ }^{(5-18)}$.

Another study with basic health units nursing staff in two cities of the metropolitan area of Rio de Janeiro demonstrated traditional methods of labor administration, shifts and tasks division, according to professional hierarchy, and predetermined activities scripts. Workers carry out their activities according to their category in an isolated and not cooperative way. The use of precepts in work management is a condition that prevents the construction of innovative activities focused on collective actions to prevent and eliminate risks and injuries of population health ${ }^{(4)}$.

The Working Conditions factor expresses the quality of the work environment, equipment and materials available to perform work activities. This factor was the one with the second highest mean score. Family Health Strategy nursing practitioners of Paraíba reported situations related to this factor that led researchers to conclude that there is a growing demand in the work environment, inadequate infrastructure, lack of personal protective equipment and presence of stress, which may expose the professional to developing illnesses. Poor working conditions, physical environment without infrastructure and lack of safety equipment can trigger injury hazards if proper protective measures are not adopted ${ }^{(10-18)}$.

The literature presents arguments that may be possibly associated with job dissatisfaction: low quality of life indicators in most of the domains for nurses of Family Health Strategies, conditions of insecurity regarding employment bond, poor remuneration, inadequacies of the environment and work organization, lack of physical safety in the workplace and high load tasks. Hence, the combination of these elements can affect the professional's physical and psychological health ${ }^{(2)}$.

Teamwork is essential for maintaining a healthy quality of life at work ${ }^{(7)}$. Socio-professional interactions are of great importance, because the human being is essentially sociable. The performance of a cooperative and affectionate work encourages its development. So the quest to improve the quality of life at work must be achieved through a good interpersonal relationship with respect and mutual support. This will result in professional satisfaction and increased productivity at work ${ }^{(17)}$.

Harmony and dialogue between the Family Health Strategy team and other workers that promote support unit must happen when planning work, this way deconstructing the division of labor and professional depreciation ${ }^{(19)}$.

With respect to the social domain, workers indicated they were satisfied with the social aspects of their lives. High means were found in other studies when it comes to social relationships, which represent the interaction with different individuals, their social environment and interpersonal interactions ${ }^{(11,13,19)}$.

The nursing team demonstrated high scores in the physical domain. Other studies conducted with nursing professionals and with the Family 
Health Strategy team also demonstrated high means toward this domain. The physical domain involves the individual's living conditions, expressed as: physical pain and discomfort, energy and fatigue, sleep and rest, mobility, activities of daily living, among others ${ }^{(11,12,20)}$.

The psychological domain deserves special attention. This obtained the lower scores, just as in a study conducted in Triângulo Sul ${ }^{(2)}$. In addition to the negative impact of low evaluation of the quality of life for the workers' health, a study must be considered for it reports feelings of displeasure, annoyance and boredom at work among participants, associated with a worse relationship with users of the service ${ }^{(4)}$.

The environmental field, with lower mean score, was represented by the facets: healthy physical environment, financial resources, participation/ opportunities for recreation and leisure and satisfaction with place of residence. These values can be justified by the precarious nature of employment, temporary employment contracts and lack of regularization of labor rights. These make the professionals to feel insecure and unhappy regarding the exercise of their duties ${ }^{(2)}$.

The salary of Family Health Strategy nurses is not compatible with their competences, as nursing is a profession that requires approximation with the reality of the population, accountability and particular competences recommended by the Ministry of Health, increasing the amount of tasks in the performance of their duties ${ }^{(2)}$. Poor remuneration may be related to the environmental field factors such as recreation and leisure activities, satisfaction with place of residence, access to health services and inadequate transport ${ }^{(12)}$. It is noteworthy that remuneration, working hours, quantity of employees and leisure are important and interfering factors in the satisfaction of the nursing staff.

The evaluation of the quality of life of Family Health Strategy nurses, in general, is influenced by the work context factors, and has an impact on the development of labor activities and the provision of care toward users' health.

\section{Conclusion}

In this study, data showed that working environment had a negative impact on quality of life.

Work Organization factor of the Work Context Assessment Scale had clearly the highest mean score, while the Socio-professional Relations factor had the lowest score. Regarding quality of life, Social domain of the WHOQOL-brief form had the highest mean score followed by the Physical and Psychological domains.

Inadequate conditions for professional practice, accelerated pace of work, demands for results and obstacles in socio-professional relations along with the lack of control over work activities and the limited autonomy of the nursing professionals who work in the Family Health Strategy can affect their quality of life and efficiency of work, with consequent implications on the quality and safety of care.

The authors of the study include the limited instruments for evaluating working environment and quality of life due to the subjectivity of such constructs. Another limitation of the study relates to the fact that understanding the impact of the work context on the quality of life for professionals in a further deepening of these themes, other than as permitted by the items of the instruments, would be possible only with a qualitative approach, thus allowing for development of future studies. Limiting the external validity is also to be taken into consideration, since the results cannot be generalized to other municipalities in the Triângulo Mineiro, not even of Minas Gerais.

Identifying work-related factors that may interfere with the quality of life of nursing professionals is essential to plan strategies to promote workers' health as well as efficiency of production processes. This is about the need to make changes that promote the general and work welfare. Therefore, this research and others realized in this direction can guide strategies for improving the working conditions of nurses of the Family Health Strategy. 


\section{Collaborations}

Marques ALN, Ferreira MBG, Duarte JMG, Costa NS Haas VJ and Simões ALA contributed to the project design, analysis and interpretation of data, article writing and final approval of the version to be published.

\section{References}

1. Tomasi ARP, Rizzotto MLF. Análise da distribuição e composição profissional dos Núcleos de Apoio à Saúde da Família no Paraná. Saúde Debate. 2013; 37(98):427-36.

2. Fernandes JS, Miranzi SSC, Iwamoto HH, Tavares DMS, Santos CB. The effects of professional factors on the quality of life of Family health team nurses. Rev Esc Enferm USP. 2012; 46(2):404-12.

3. Kian KO, Matsuda LM, Waidmann MAP. Compreendendo o cotidiano do profissional do enfermeiro-líder. Rev Rene. 2011; 12(4):724-31.

4. David HMSL, Mauro MYC, Silva VG, Pinheiro AS, Silva FH. Organização do trabalho de enfermagem na Atenção Básica: Uma questão para a saúde do trabalhador. Texto Contexto Enferm. 2009; 18(2):206-14.

5. Shimizu HE, Carvalho Junior DA. O processo de trabalho na Estratégia Saúde da Família e suas repercussões no processo saúde-doença. Ciênc Saúde Coletiva. 2012; 17(9):2405-14.

6. Fleck MPA, Lousada S, Xavier M, Chachamovich E, Vieira G, Santos LP, et al. Aplicação da versão em português do instrumento abreviado de avaliação da Qualidade de vida WHOQOL-bref. Rev Saúde Pública. 2000; 34(2):178-83.

7. Daubermann DC, Tonete VLP. Quality of work life of nurses in primary health care. Acta Paul Enferm. 2012; 25(2):277-83.

8. Mendes AM, Ferreira MC. Contexto de trabalho. In: Siqueira MMM. Medidas do comportamento organizacional: ferramentas de diagnóstico e gestão. Porto Alegre: Artmed; 2008. p.111-23.
9. Fernandes JS, Miranzi SSC, Iwamoto HH, Tavares DMS, Santos CB. Qualidade de vida dos enfermeiros das equipes de saúde da família: a relação das variáveis sociodemograficas. Texto Contexto Enferm. 2010; 19(3):434-42.

10. Silva CCS, Rodrigues LMC, Silva VKBA, Silva ACO, Silva VLA, Martins MO. Percepção da enfermagem sobre condições de trabalho em unidades de saúde da família na Paraíba-Brasil. Rev Eletr Enf. [periódico na Internet]. 2013 [citado $2015 \mathrm{mar}$ 12]; 15(1):205-14. Disponível em: https://www. fen.ufg.br/fen_revista/v15/n1/pdf/v15n1a24. pdf

11. Lopes AOS, Macedo APB. Avaliação da qualidade de vida de enfermeiros da atenção básica. Inter Sci. 2013; 1(3):16-27.

12. Maciel MED, Oliveira FNO. Qualidade de vida do profissional técnico de enfermagem: a realidade de um hospital filantrópico em Dourados-MS. Rev Psicol Saúde. 2014; 6(1):83-9.

13. Rios KA, Barbosa DA, Belasco AG. Evaluation of quality of life and depression in nursing technicians and nursing assistants. Rev Latino-Am Enfermagem. 2010; 18(3):413-20.

14. Silva VG, Motta MCS, Zeitoune RCG. A prática do enfermeiro na Estratégia Saúde da Família: o caso do município de Vitória/ES. Rev Eletr Enf. [periódico na Internet]. 2010 [citado $2015 \mathrm{mar}$ 16]; 12(3):441-8. Disponível em: http://dx.doi. org/10.5216/ree.v12i3.5278

15. Ferrari GLS, Wadi JML, Ferrari CKB. Qualidade de vida em profissionais da Estratégia de Saúde da Família (ESF) no Vale do Araguaia, Amazônia Legal, Brasil. Scire Salutis. 2013; 3(1):78-85.

16. Feitosa LG, Simonetti AS, Ferraz BER, Kobayashi RM. Caracterização do estresse de enfermeiros que atuam em hospital especializado em cardiologia. Rev Electr Trimestr Enferm. [periódico na Internet]. 2012 [citado 2015 mar 16]; 11(4):10519. Disponível em: http://dialnet.unirioja.es/ servlet $/$ revista? codigo $=2480$ 
17. Mitsi SM, Medeiros SM, Freitas JAC. Influência do contexto de trabalho na saúde dos profissionais de enfermagem de uma unidade de terapia intensiva em um hospital universitário. Rev Electr Trimestr Enferm. [periódico na internet]. 2013 [citado 2015 mar 18]; 12(32):185-97. Disponível em: http:// dialnet.unirioja.es/servlet/revista?codigo $=2480$

18. Campos JF, David HSL. Work Context Assessment in intensive therapy units from the perspective of work psychodynamics. Rev Esc Enferm USP. 2011; 45(2):363-8.
19. Viegas SMF, Penna CMM. A construção da integralidade no trabalho cotidiano da equipe saúde da família. Esc Anna Nery. 2013; 17(1):13341.

20. Gessner CLS, Grillo LP, Sandri JVA, Próspero ENS, Mariath AB. Qualidade de vida de trabalhadores de equipes de saúde da família no sul do Brasil. Rev Bras Pesq Saúde. 2013; 15(3):30-7. 